Our ref: Nussenblatt fig 4e/tab no. [Please quote on all correspondence]

Tuesday, 10 November 2009

Conselho Brasileiro de Oftalmologia

Alameda Santos, 1.343 - $11^{\circ}$ andar - cj. 1.110

CEP 01419-001 - São Paulo (SP) - Brazil

Tel: 11 - 3266-4000 - Fax: 11 - 3171-0953

E-mail:abo@cbo.com.br

Dear Sir/Madam:

\title{
PERMISSIONS REQUEST AND RETURN PROFORMA
}

We are preparing a book to be published by Elsevier Inc. provisionally entitled:

Nussenblatt \& Whitcup, Uveitis $4^{\text {th }}$ Edition.

We should like to include the below material (Elsevier Inc. Fig 17.7) from:

A case of anterior internal ophthalmomyiasis: case report Arq Bras Ofthalmol. 2006;69, Vinicius da Silveira Saraiva, Miguel Hage Amaro, Rubens Belfort Jr., Miguel Noel Burnier Jr.

I request your permission to reproduce this material worldwide in this book, in all subsequent editions, revisions and translations of it in print and in all other forms of media, now or hereafter known (including journals, CD-ROMs, online and internet), derivative works based on this book, and other publications published by Elsevier, Inc.

SPECIFICALLY, I REQUEST PERMISSIONTO REPRODUCE THIS MATERIAL IN ELECTRONIC AS WELL AS PRINT VERSIONS OF THIS BOOK.
Unless you indicate otherwise, a suitable acknowledgement will be given to the author, including the complete reference listed above.

Please indicate your agreement by signing and returning a copy of this letter as well as or instead of your own invoice. If you do not control the rights to this material, please let me know whom I should contact. PLEASE ENSURE THAT ANY INVOICE IS ADDRESSED TO ELSEVIER, INC.

I should be grateful if you would deal with this request at your earliest convenience.

Yours faithfully,

Poppy Garraway* Editorial Assistant

* Poppy Garraway Elsevier Inc.

Correspondence address: 32 Jamestown Road - London, NW1 7BY

Tel: +44 (0) 2074244234 - Fax: + 44 (0) 2074244652 - E-mail: p.garraway @elsevier.com

\section{Resposta da "Carta ao Editor" - solicitação do Dr. Nussenblatt}

We are pleased to annex you the authorization form relative to the permission request you have sent to us, about the article "A case of anterior internal ophthalmomyiasis: case report". Arq Bras Oftalmol. 2006;69. Vinicius da Silveira
Saraiva, Miguel Hage Amaro, Rubens Belfort Jr., Miguel Noel Burnier Jr.

Faithfully yours,

Harley E. A. Bicas Editor-in-Chief Arquivos Brasileiros de Oftalmologia 